\title{
RELEVANSI KURIKULUM SMK BERBASIS INDUSTRI KREATIF DENGAN METODE EXTRAPOLATION AND THE ECONOMETRIC APPROACH
}

\author{
Isma Widiaty \\ Program Studi Pendidikan Kesejahteraan Keluarga \\ FPTK Universitas Pendidikan Indonesia \\ J1. Dr. Seiabudhi 207 Bandung \\ ismakurnia@yahoo.co.id
}

\begin{abstract}
Abstrak: Tujuan dari penelitian ini adalah mengkaji profil industri kreatif bidang fesyen dalam upaya mengembangkan kurikulum SMK program keahlian Tata Busana yang relevan dengan kebutuhan dunia industri. Metode penelitian yang digunakan yaitu extrapolation and the econometric approach. Relevansi kurikulum yang dikaji dilihat dari dimensi kualitas, kuantitas, lokasi, dan waktu. Hasil kajian memperlihatkan bahwa industri kreatif bidang fesyen dari aspek kualitas memerlukan kompetensi lulusan yang memiliki aspek hardskill dan softskill yang berbasis pada kreativitas. Dimensi kuantitas dan lokasi menunjukkan bahwa lulusan SMK Tata Busana memiliki peluang yang cukup besar untuk bekerja di industri kreatif bidang fesyen khususnya yang berada di Kota Bandung (dimensi lokasi). Terakhir, dari dimensi waktu industri kreatif bidang fesyen perlu menjadi program keahlian yang dikembangkan secara serius di masa kini dan masa depan.
\end{abstract}

Kata kunci : industri kreatif fesyen, relevansi kurikulum SMK

\begin{abstract}
The purpose of this study is to examine the profile of the fashion creative industries in developing Vocational High School curriculum of dressmaking skills program relevant to the needs of the industry. The research method used is extrapolation and the econometric approach. The relevance of the curriculum studied is viewed from the dimensions of quality, quantity, location, and time. The study results showed that the creative industries of fashion field quality aspects require graduate with competencies softskill and hardskill aspects based on creativity. Dimensional quantity indicates that graduates of vocational skills program fashion has a big opportunity to work in the creative field of fashion industry especially in the City of Bandung (the location dimension). Last, time dimension of creative industries of fashion sector needs to be developed as programming skill seriously in the present and the future.
\end{abstract}

Keywords : fashion creative industries, relevancy of curriculum

\section{PENDAHULUAN}

Masalah relevansi kurikulum di pendidikan kejuruan menjadi isu yang krusial sepanjang masa. Merancang kurikulum yang relevan di pendidikan kejuruan merupakan tugas yang harus terus menerus dilakukan seiring dengan perkembangan zaman yang terus berubah pula (Oloruntegbe,2010). Relevansi kurikulum memiliki dua mata pisau, apakah akan menjadi kekuatan terbesar atau bahkan menjadi kelemahan terbesar dalam pendidikan kejuruan. Kurikulum pendidikan kejuruan yang dikembangkan dengan selalu mengacu pada prinsip 
relevansi ini, merupakan dasar bagi begitu banyak keputusan penting yang akan memberikan arah yang tepat bagi keberhasilan perencanaan dan implementasi program di pendidikan kejuruan (Komla, 2011).

Relevansi kurikulum dimaknai sebagai the adaptive curriculum (Sanjaya,2008). Kurikulum memiliki fungsi sebagai penyesuaian (the adjustive). Makna penyesuaian adalah kurikulum harus memiliki kemampuan untuk menyesuaikan diri dengan perkembangan masyarakat, ilmu pengetahuan, teknologi, dan kebutuhan dunia kerja. Perkembangan dunia kerja bersifat dinamis dan berubah secara cepat sesuai dengan perkembangan ilmu pengetahuan dan teknologi.

Relevansi akan menghubungkan antara potensi lapangan kerja yang ada dan kemampuan lulusan untuk memenuhi persyaratan pekerjaan tersebut. Apabila lulusan dari pendidikan kejuruan tidak dapat memenuhi persyaratan dan kebutuhan yang telah ditetapkan lapangan pekerjaan, maka pendidikan kejuruan dianggap "gagal” (Canavan, 2005; Hodge, 2011; Miller, 1985). Perubahan yang sangat cepat di dunia kerja mengisyaratkan bahwa kurikulum perlu selalu ditinjau ulang untuk melihat apakah masih ada kecocokan antara apa yang diajarkan di sekolah dengan kebutuhan dunia kerja. Relevansi ini menjadi suatu kata yang sangat penting untuk mencapai tujuan dari pendidikan kejuruan itu sendiri. Kurikulum pendidikan kejuruan harus dirancang sesuai kebutuhan dunia kerja. Kurikulum pendidikan kejuruan dan kebutuhan dunia kerja harus memiliki prinsip go hand in hand (Miller,1985; Oloruntegbe, 2010).

Sekolah Menengah Kejuruan (SMK) sebagai bagian penting dari sistem pendidikan kejuruan memiliki tujuan yaitu “..... mempersiapkan peserta didik terutama untuk bekerja dalam bidang tertentu ". (Undang-Undang Sistem Pendidikan Nasional No.20 Tahun 2003 pasal 15). Fakta di lapangan menunjukkan gejala yang cukup memprihatinkan dimana lulusan SMK memiliki prosentase terbesar dalam pengangguran, sebagaimana ditunjukkan pada Gambar 1.

Kondisi ini akan menjadi lebih kritis apabila dikaitkan dengan kebijakan pemerintah yang tertuang pada Renstra Kemendiknas 2010-2014, dimana proporsi rasio jumlah SMK dan SMU dirubah menjadi 67\% SMK : 33\% SMU . 
Rasio peningkatan jumlah SMK yang sangat signifikan akan berakibat pada bertambahnya jumlah angkatan kerja. Persoalan baru akan muncul apabila jumlah angkatan kerja lulusan SMK tersebut tidak dibarengi dengan kualifikasi yang memadai yang sesuai dengan kebutuhan dunia kerja .

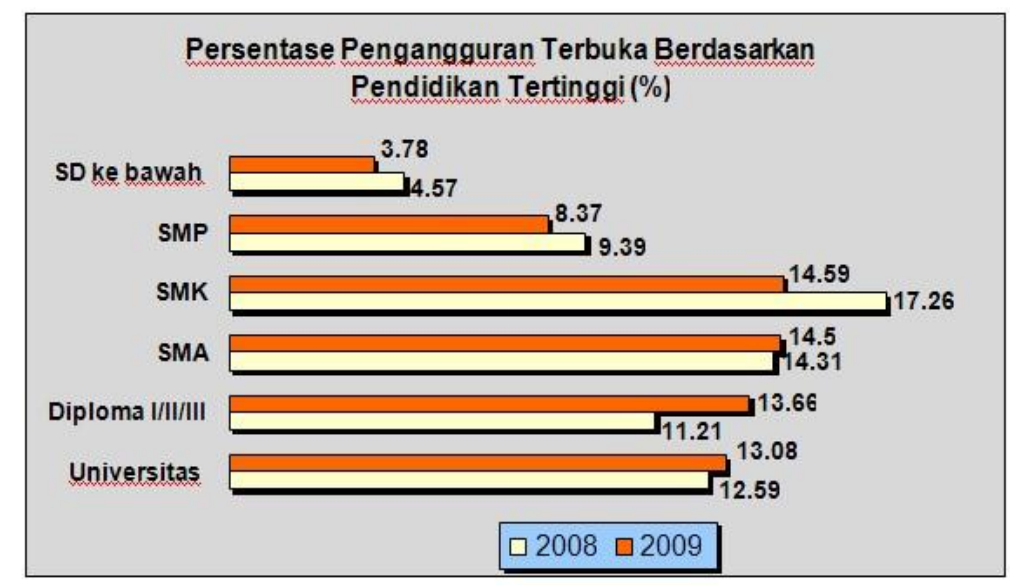

(Sumber : BPS)

Gambar 1. Prosentase pengangguran terbuka berdasarkan jenjang pendidikan

Indikator relevansi kurikulum SMK yang masih rendah didukung oleh hasil penelitian Badan Penelitian dan Pengembangan Provinsi Jawa Tengah (2008) bahwa jumlah lulusan yang dapat diserap dunia kerja berjumlah kurang dari 50\%. Studi GTZ (2009) memperlihatkan gambaran bahwa output pendidikan SMK khususnya dalam aspek softskills belum sesuai dengan kebutuhan dunia industri. Masalah ini disebabkan oleh sistem pendidikan (termasuk di dalamnya kurikulum) SMK belum mampu membekali siswa dengan keahlian yang relevan dengan kebutuhan dunia kerja. Oloruntegbe (2010) mengemukakan bahwa kualitas lulusan pendidikan kejuruan yang unemployable akan menyebabkan pengaruh yang kurang menguntungkan pada perekonomian suatu negara sehingga akan menimbulkan gejala economically inactive. Amankwah (2011) mengemukakan bahwa vocational education plays a key role in economical, social, and political developtment of every nation.

Industri kreatif menjadi bagian penting dari kebangkitan ekonomi suatu negara. Departemen Perdagangan RI (2009) mengemukakan bahwa industri kreatif mampu menyumbangkan nilai tambah Produk Domestik Bruto (PDB) yang cukup signifikan. Industri fesyen menjadi kontributor terbesar di antara 
industri kreatif yang lain. Profil industri kreatif dapat dijadikan bahan untuk mengkaji aspek relevansi kurikulum SMK program keahlian Tata Busana.

\section{METODE}

Pendekatan penelitian yang digunakan adalah extrapolation and the econometric approach. Pendekatan ini dapat digunakan untuk membaca kecenderungan demand tenaga kerja masa kini yang dapat dijadikan "forecasting" pada masa depan. Prosedur penelitian yang dilakukan sebagaimana ditunjukkan pada Gambar 2.

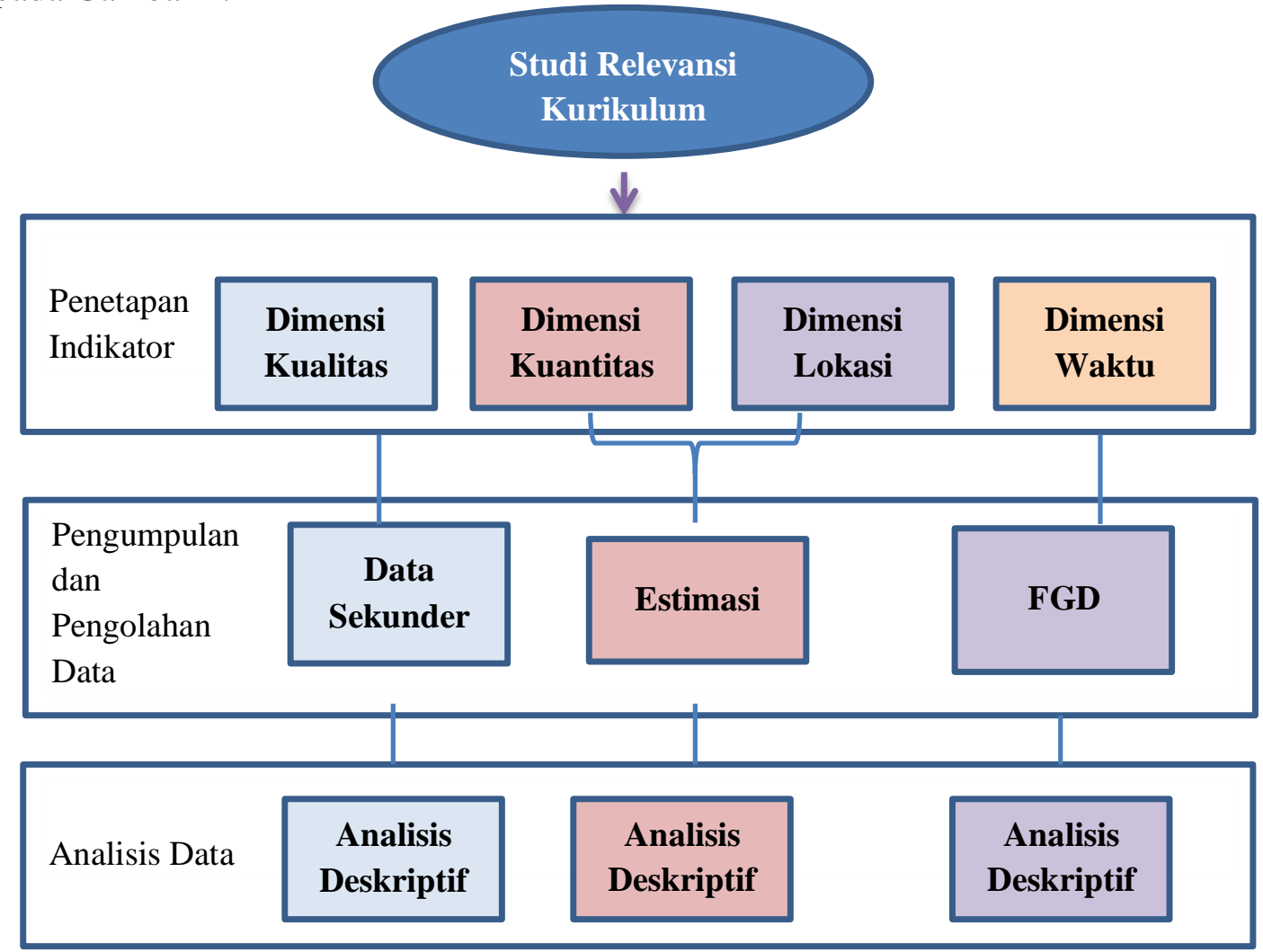

Gambar 2. Prosedur Penelitian

Model penyelarasan pendidikan yang dikembangkan oleh Tim Ahli Penyelarasan Pendidikan dan Dunia Kerja (2011) dipakai oleh penulis untuk membantu dalam menganalisis data penelitian. Penetapan indikator yang digunakan terdiri dari empat dimensi, yaitu dimensi kualitas, kuantitas, waktu, dan lokasi. Model penyelarasan sebagaimana terlihat dalam gambar 3. 


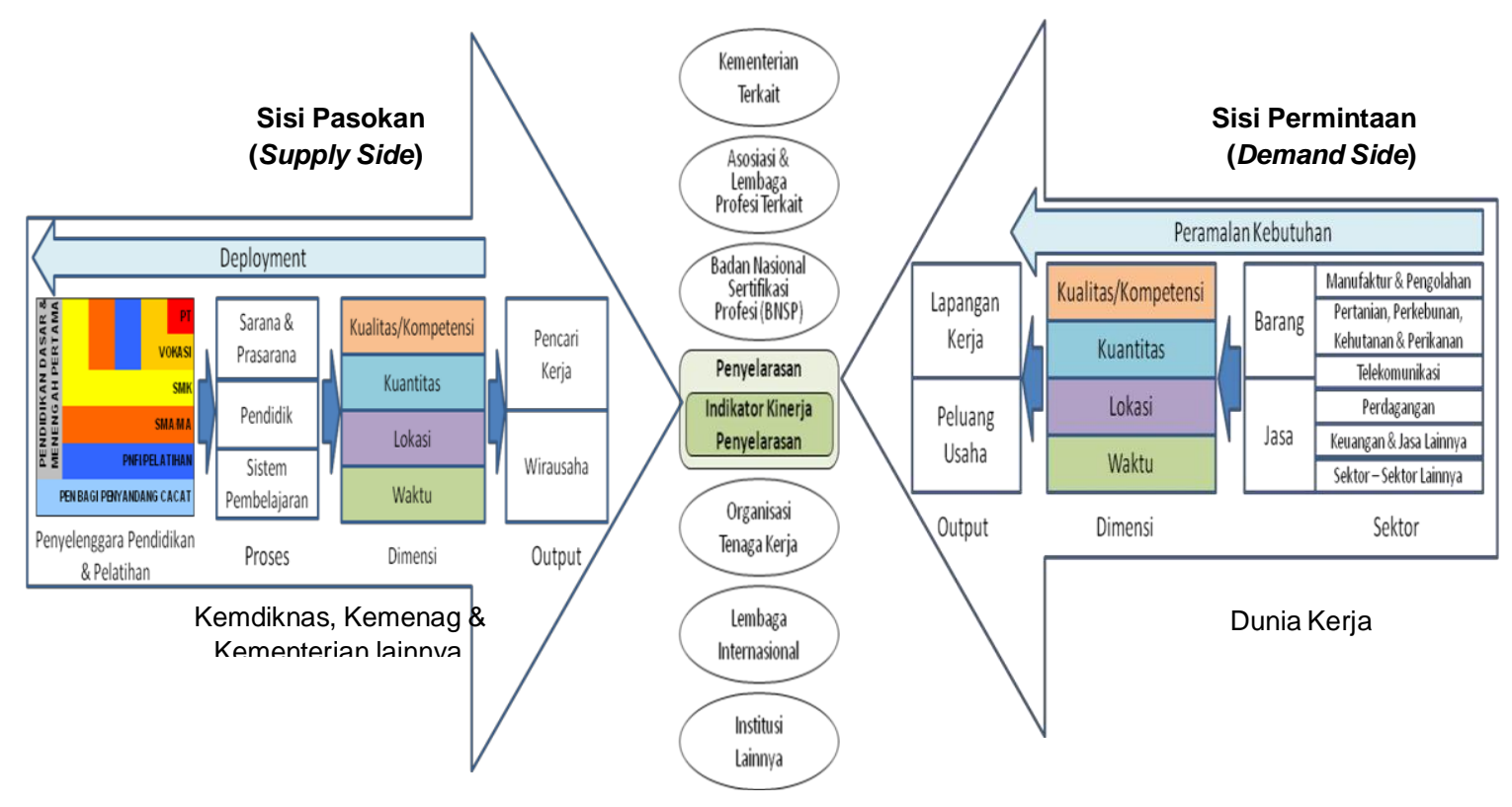

Gambar 3. Model penyelarasan pendidikan dan dunia kerja

Penelitian yang dilakukan akan lebih banyak membahas aspek sisi permintaan (demand side) yang bersumber dari data industri kreatif bidang fesyen yang akan menjadi bahan informasi berharga bagi para pengembang kurikulum di SMK khususnya agar kurikulum yang dikembangkan dapat relevan dengan kebutuhan dunia kerja.

\section{HASIL DAN PEMBAHASAN}

\section{Relevansi Kurikulum SMK Dimensi Kualitas}

Profil industri kreatif menjadi informasi penting bagi pengembangan kurikulum di pendidikan kejuruan (SMK). Industri kreatif pada umumnya merupakan industri yang dikelola secara individual. Ide kreatif menjadi modal utama untuk mengembangkan industri kreatif. Pada umumnya industri kreatif lahir dan berkembang di kota-kota besar dan menjadi penopang pertumbuhan ekonomi di wilayah tersebut. Sebagian besar pengelola industri kreatif adalah anak muda yang memiliki ide-ide orisinal dan kreatif . Industri kreatif selalu memanfaatkan sarana teknologi informasi dan komunikasi (jaringan internet: twitter, facebook, e-commerce ) sebagai sarana promosi maupun mengeksplor ideide kreatif (Anggraeni:2008). 
Profil industri kreatif yang telah diuraikan menggambarkan kompetensi yang harus dimiliki oleh para pelaku industri kreatif. Kompetensi yang dimaksud diantaranya: kreatif dan mampu menghasilkan produk yang kreatif, terbuka, serta "melek" teknologi. Unsur kreativitas ini menjadi kompetensi paling penting yang harus dimiliki oleh pelaku industri kreatif. Munandar (1999) mendefinisikan salah satu dimensi kreativitas adalah dimensi person. Dimensi person merupakan kompetensi yang berfokus pada proses berpikir seseorang sehingga memunculkan ide unik atau kreatif dalam bidang fesyen. Hasil kreativitas, imaginasi, dan fantasi ini akan menghasilkan produk kreatif bidang fesyen yang memiliki karakteristik produk yang orisinil.

Dimensi kualitas yang bersumber dari perkembangan industri kreatif bidang fesyen dapat dikaji pula dari kategori produk yang dihasilkan oleh tenaga kerja di industri kreatif bidang fesyen ini, sebagaimana ditunjukkan pada gambar 4:

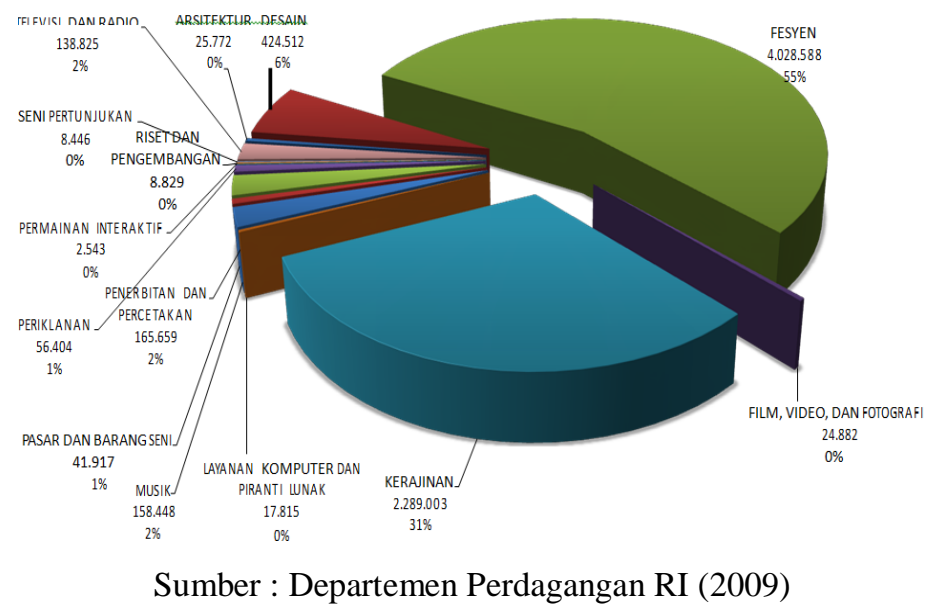

Gambar 4. Rata-rata jumlah dan tingkat partisipasi tenaga kerja industri kreatif

Subsektor fesyen merupakan pemberi kontribusi terbesar di antara 14 subsektor industri kreatif, dengan rata-rata kontribusi 2002 - 2008 mencapai 55\% atau sekitar 4.028.588 tenaga kerja. Setengah dari jumlah tenaga kerja tersebut berada pada lini produksi pakaian jadi, sisanya bergerak dalam bidang distribusi dan perdagangan eceran (Departemen Perdagangan RI,2009:121). Profil industri kreatif dimensi kualitas menjadi data berharga untuk mengembangkan kurikulum pendidikan kejuruan. Jenis usaha ini akan memberi gambaran sub kompetensi 
yang perlu dikembangkan dalam kurikulum SMK yang diturunkan dari kompetensi utama sebagai produsen pakaian jadi.

Industri kreatif bidang fesyen Indonesia telah memiliki daya jual yang cukup tinggi. Kondisi ini terbukti dari nilai eksport produk tersebut sebagaimana ditunjukkan pada tabel 1 .

Tabel 1. Perbandingan ekspor sektor industri kreatif bidang fesyen nasional 2002-2008

\begin{tabular}{|c|c|c|c|c|c|c|c|c|}
\hline \begin{tabular}{l|l} 
NO & LAPANGAN USAHA INDUSTRI KREATIF \\
\end{tabular} & 2002 & 2003 & 2004 & 2005 & 2006 & 2007 & 2008 & Rata-rata \\
\hline 1 FESYEN & $36.269,93$ & $35.261,90$ & $45.563,82$ & $51.042,26$ & $54.714,62$ & $57.908,31$ & $71.695,51$ & $50.350,91$ \\
\hline 2 KERAJINAN & $20.108,11$ & $19.608,2 C$ & $21.741,5 \mathrm{C}$ & $22.673,16$ & $27.292,61$ & $34.351,71$ & $39.673,98$ & $26.492,75$ \\
\hline 3 DESAIN & $1.111,98$ & $1.499,86$ & $1.843,69$ & $2.169,72$ & $2.214,05$ & $2.396,03$ & $2.892,01$ & $2.018,19$ \\
\hline 4 MUSIK & 724,46 & $1.004,43$ & 379,26 & 225,99 & 238,30 & 131,41 & 77,82 & 397,38 \\
\hline 5 PENERBITAN DAN PERCETAKAN & 103,75 & 90,14 & 93,73 & 180,51 & 161,14 & 133,65 & 173,35 & 133,75 \\
\hline GPERMAINAN INTERAKTIF & 32,17 & $39,7 €$ & 53,78 & 68,39 & 75,38 & $132,2 \mathrm{C}$ & 170,23 & 81,70 \\
\hline 7 PASAR DAN BARANG SENI & 38,10 & 43,17 & 38,67 & 60,03 & 78,03 & 82,50 & 108,41 & 64,13 \\
\hline 8PERIKLANAN & 23,17 & 47,75 & 51,67 & 39,37 & 64,63 & 72,28 & 132,48 & 61,62 \\
\hline 9 FILM, VIDEO, DAN FOTOGRAFI & 0,94 & 1,71 & 7,56 & 2,55 & 1,19 & 0,45 & 1,07 & 2,21 \\
\hline 1CARSITEKTUR & 0,09 & 0,25 & 0,21 & 0,06 & 0,24 & 0,07 & 0,11 & 0,15 \\
\hline 11 LAYANAN KOMPUTER DAN PIRANTI LUNAK & - & - & - & - & - & - & - & - \\
\hline 12RISET DAN PENGEMBANGAN & - & - & - & - & - & - & - & - \\
\hline 13 SENI PERTUNJUKAN & - & - & - & - & - & - & - & - \\
\hline 14TELEVISI DAN RADIO & - & - & - & - & - & - & - & - \\
\hline Total & 58.413 & 57.597 & 69.774 & 76.462 & 84.840 & 95.209 & 114.925 & 79.603 \\
\hline
\end{tabular}

Aspek ekspor sektor industri nasional tahun 2002-2008 fesyen merupakan subsektor yang mendominasi dan tertinggi dengan rata-rata nilai ekspor mencapai Rp 50,35 triliun atau sekitar 63\%. Peluang pasar ekspor yang menjanjikan ini terkait dengan dimensi kompetensi dan wilayah dari relevansi kurikulum. Produk industri kreatif yang berorientasi ekspor tentu saja akan menuntut kompetensi yang lebih tinggi bagi pelaku-pelaku di bidang industri kreatif bidang fesyen .

\section{Relevansi Kurikulum SMK Dimensi Kuantitas}

Relevansi kurikulum SMK dimensi kuantitas dapat dikaji dari jumlah lapangan pekerjaan yang tersedia sebagaimana ditunjukkan pada tabel 2 .

Jumlah lapangan kerja industri kreatif fesyen menduduki peringkat satu selama delapan tahun berturut-turut. Selain itu, jumlah prosentase peluang lapangan kerja yang tersedia hampir mencapai setengah $(45,78 \%)$ dari total 14 sektor industri kreatif lainnya. Aspek demand side lulusan dari dunia pendidikan yang dibutuhkan dunia kerja dapat dinalisis dari dimensi kualitas ini. Idealnya SMK program keahlian Tata Busana menjadi kontributor utama untuk mampu menjadi pemasok tenaga kerja bagi industri kreatif bidang fesyen ini. Bagi para pengembang kurikulum, data ini dapat menjadi peta untuk pengembangan 
"spektrum" program keahlian SMK sehingga program keahlian yang dikembangkan memang sesuai dengan kebutuhan dunia kerja. Finch and Cruncilton (1992) memberikan gambaran bahwa proyeksi kebutuhan lapangan pekerjaan (employment) saat ini dan di masa yang akan datang merupakan bahan yang sangat berharga bagi pengembang kurikulum agar kurikulum yang dikembangkan relevan dengan kebutuhan lapangan pekerjaan yang ada. Salah satu strategi untuk mengidentifikasi kebutuhan tersebut, yaitu menganalisis emerging industries seperti industri kreatif.

Tabel 2. Jumlah lapangan kerja industri kreatif bidang fesyen nasional 2002-2008

\begin{tabular}{|c|c|c|c|c|c|c|c|c|c|}
\hline NO & LAPANGAN USAHAINDUSTRI KREATIF & 2002 & 2003 & 2004 & 2005 & 2006 & 2007 & 2008 & Rata-rata \\
\hline \multicolumn{2}{|c|}{1 FESYEN } & $52,18 \%$ & $49,77 \%$ & $47,02 \%$ & $44,75 \%$ & $44,93 \%$ & $43,55 \%$ & $43,48 \%$ & $45,78 \%$ \\
\hline \multicolumn{2}{|c|}{2 KERAJINAN } & $23,42 \%$ & $23,76 \%$ & $23,29 \%$ & $23,60 \%$ & $24,51 \%$ & $25,30 \%$ & $24,59 \%$ & $24,23 \%$ \\
\hline \multicolumn{2}{|c|}{3 DESAIN } & $7,19 \%$ & $7,03 \%$ & $6,54 \%$ & $6,80 \%$ & $6,15 \%$ & $6,42 \%$ & $6,38 \%$ & $6,57 \%$ \\
\hline \multicolumn{2}{|c|}{4 PERIKLANAN } & $4,15 \%$ & $5,28 \%$ & $5,78 \%$ & $5,96 \%$ & $6,92 \%$ & $7,18 \%$ & $7,58 \%$ & $6,42 \%$ \\
\hline \multicolumn{2}{|r|}{5 PENERBITAN DAN PERCETAKAN } & $4,34 \%$ & $4,35 \%$ & $5,75 \%$ & $5,67 \%$ & $5,21 \%$ & $5,09 \%$ & $5,01 \%$ & $5,10 \%$ \\
\hline \multicolumn{2}{|c|}{6 MUSIK } & $3,04 \%$ & $3,47 \%$ & $5,03 \%$ & $5,83 \%$ & $5,08 \%$ & $5,14 \%$ & $5,23 \%$ & $4,85 \%$ \\
\hline \multicolumn{2}{|c|}{7 ARSITEKTUR } & $2,07 \%$ & $2,25 \%$ & $2,36 \%$ & $2,73 \%$ & $2,37 \%$ & $2,47 \%$ & $2,59 \%$ & $2,44 \%$ \\
\hline \multicolumn{2}{|c|}{8 TELEVISI DAN RADIO } & $1,21 \%$ & $1,40 \%$ & $1,47 \%$ & $1,54 \%$ & $1,53 \%$ & $1,57 \%$ & $1,64 \%$ & $1,51 \%$ \\
\hline \multicolumn{2}{|r|}{9 LAYANAN KOMPUTER DAN PIRANTI LUNAK } & $0,54 \%$ & $0,66 \%$ & $0,75 \%$ & $0,93 \%$ & $1,07 \%$ & $1,12 \%$ & $1,19 \%$ & $0,95 \%$ \\
\hline \multicolumn{2}{|c|}{10 RISET DAN PENGEMBANGAN } & $0,60 \%$ & $0,63 \%$ & $0,63 \%$ & $0,68 \%$ & $0,68 \%$ & $0,71 \%$ & $0,75 \%$ & $0,68 \%$ \\
\hline \multicolumn{2}{|c|}{11 FILM, VIDEO, DAN FOTOGRAFI } & $0,54 \%$ & $0,56 \%$ & $0,56 \%$ & $0,60 \%$ & $0,58 \%$ & $0,60 \%$ & $0,63 \%$ & $0,59 \%$ \\
\hline \multicolumn{2}{|c|}{12 PASAR DAN BARANG SENI } & $0,46 \%$ & $0,55 \%$ & $0,50 \%$ & $0,55 \%$ & $0,57 \%$ & $0,43 \%$ & $0,47 \%$ & $0,50 \%$ \\
\hline \multicolumn{2}{|c|}{13 PERMAINAN INTERAKTIF } & $0,19 \%$ & $0,22 \%$ & $0,23 \%$ & $0,27 \%$ & $0,29 \%$ & $0,32 \%$ & $0,36 \%$ & $0,28 \%$ \\
\hline \multicolumn{2}{|c|}{14 SENI PERTUNJUKAN } & $0,07 \%$ & $0,09 \%$ & $0,09 \%$ & $0,09 \%$ & $0,09 \%$ & $0,10 \%$ & $0,10 \%$ & $0,09 \%$ \\
\hline \multicolumn{2}{|l|}{ Total } & $100 \%$ & $100 \%$ & $100 \%$ & $100 \%$ & $100 \%$ & $100 \%$ & $100 \%$ & $100 \%$ \\
\hline
\end{tabular}

Aspek kedua terkait dengan relevansi kurikulum dimensi kuantitas adalah indikator daya serap tenaga kerja industri kreatif bidang fesyen sebagaimana ditunjukkan pada tabel 3 .

Tabel 3. Daya serap tenaga kerja industri kreatif bidang fesyen nasional 2002-2008

\begin{tabular}{|c|c|c|c|c|c|c|c|c|}
\hline NO LAPANGAN USAHA INDUSTRI KREATIF & 2002 & 2003 & 2004 & 2005 & 2006 & 2007 & 2008 & Rata-rata \\
\hline 1 ARSITEKTUR & 20.658 & 27.165 & 24.373 & 23.856 & 25.963 & 28.037 & 30.349 & 25.772 \\
\hline 2 DESAIN & 477.908 & 351.139 & 500.134 & 473.350 & 369.830 & 390.298 & 408.923 & 424.512 \\
\hline 3 FESYEN & 4.419 .590 & 3.571 .127 & 4.057 .493 & 4.037 .705 & 3.851 .949 & 4.052 .329 & 4.209 .920 & 4.028 .588 \\
\hline 4 FILM, VIDEO, DAN FOTOGRAFI & 22.886 & 22.188 & 23.169 & 22.640 & 26.032 & 27.759 & 29.502 & 24.882 \\
\hline 5 KERAJINAN & 2.564 .214 & 2.178 .880 & 2.268 .898 & 2.144 .951 & 2.173 .502 & 2.304 .037 & 2.388 .536 & 2.289 .003 \\
\hline 6 LAYANAN KOMPUTER DAN PIRANTI LUNAK & 15.236 & 18.644 & 18.083 & 17.506 & 16.448 & 18.247 & 20.543 & 17.815 \\
\hline 7 MUSIK & 178.807 & 145.731 & 206.962 & 234.128 & 111.298 & 115.773 & 116.438 & 158.448 \\
\hline 8 PASAR DAN BARANG SENI & 36.819 & 38.321 & 40.644 & 40.309 & 42.812 & 45.755 & 48.759 & 41.917 \\
\hline 9 PENERBITAN DAN PERCETAKAN & 178.852 & 143.221 & 141.280 & 159.932 & 173.149 & 180.637 & 182.544 & 165.659 \\
\hline 10 PERIKLANAN & 41.423 & 63.790 & 59.656 & 51.950 & 54.792 & 59.169 & 64.047 & 56.404 \\
\hline 11 PERMAINAN INTERAKTIF & 1.760 & 2.505 & 2.267 & 2.036 & 2.662 & 3.032 & 3.537 & 2.543 \\
\hline 12 RISET DAN PENGEMBANGAN & 7.922 & 9.733 & 8.588 & 8.034 & 8.473 & 9.150 & 9.904 & 8.829 \\
\hline 13 SENI PERTUNJUKAN & 7.334 & 7.539 & 8.420 & 8.216 & 8.599 & 9.190 & 9.821 & 8.446 \\
\hline 14 TELEVISI DAN RADIO & 116.867 & 120.606 & 137.918 & 135.420 & 143.882 & 153.499 & 163.586 & 138.825 \\
\hline Total & 8.090 .276 & 6.700 .589 & 7.497 .885 & 7.360 .032 & 7.009 .392 & 7.396 .913 & 7.686 .410 & 7.391 .642 \\
\hline
\end{tabular}

Sumber : Departemen Perdagangan RI (2009) 
Tingkat daya serap industri kreatif bidang fesyen menempati urutan pertama. Kecenderungan ini dapat menjadi informasi bagi SMK Tata Busana bahwa lulusan yang dibutuhkan dunia kerja relatif banyak. Daya serap lulusan dan jumlah lapangan usaha industri menjadi indikator untuk mengembangkan kurikulum yang relevan dilihat dari dimensi kuantitas.

Tabel 4. Jumlah usaha industri kreatif bidang fesyen nasional 2002-2008

\begin{tabular}{|c|c|c|c|c|c|c|c|c|}
\hline NO LAPANGAN USAHA INDUSTRI KREATIF & 2002 & 2003 & 2004 & 2005 & 2006 & 2007 & 2008 & Rata-rata \\
\hline 1 FESYEN & $50,36 \%$ & $50,28 \%$ & $52,39 \%$ & $53,04 \%$ & $51,94 \%$ & $51,71 \%$ & $51,97 \%$ & $51,66 \%$ \\
\hline 2 KERAIINAN & $36,87 \%$ & $38,01 \%$ & $34,30 \%$ & $32,84 \%$ & $35,17 \%$ & $35,34 \%$ & $35,16 \%$ & $35,38 \%$ \\
\hline 3 DESAIN & $8,21 \%$ & $7,20 \%$ & $9,35 \%$ & $9,54 \%$ & $7,19 \%$ & $7,15 \%$ & $7,13 \%$ & $7,99 \%$ \\
\hline 4 PENERBITAN DAN PERCETAKAN & $2,87 \%$ & $2,77 \%$ & $2,34 \%$ & $2,77 \%$ & $3,66 \%$ & $3,78 \%$ & $3,68 \%$ & $3,11 \%$ \\
\hline 5 MUSIK & $0,29 \%$ & $0,33 \%$ & $0,37 \%$ & $0,42 \%$ & $0,50 \%$ & $0,48 \%$ & $0,47 \%$ & $0,41 \%$ \\
\hline GPASAR DAN BARANG SENI & $0,30 \%$ & $0,40 \%$ & $0,32 \%$ & $0,35 \%$ & $0,40 \%$ & $0,39 \%$ & $0,39 \%$ & $0,36 \%$ \\
\hline 7 FILM, VIDEO, DAN FOTOGRAFI & $0,63 \%$ & $0,31 \%$ & $0,24 \%$ & $0,24 \%$ & $0,24 \%$ & $0,24 \%$ & $0,23 \%$ & $0,31 \%$ \\
\hline 8 LAYANAN KOMPUTER DAN PIRANTI LUNAK & $0,20 \%$ & $0,28 \%$ & $0,25 \%$ & $0,28 \%$ & $0,27 \%$ & $0,28 \%$ & $0,30 \%$ & $0,27 \%$ \\
\hline 9 PERIKLANAN & $0,09 \%$ & $0,17 \%$ & $0,18 \%$ & $0,23 \%$ & $0,26 \%$ & $0,26 \%$ & $0,26 \%$ & $0,20 \%$ \\
\hline 10 ARSITEKTUR & $0,04 \%$ & $0,07 \%$ & $0,08 \%$ & $0,11 \%$ & $0,14 \%$ & $0,14 \%$ & $0,14 \%$ & $0,10 \%$ \\
\hline 11 TELEVISI DAN RADIO & $0,07 \%$ & $0,08 \%$ & $0,07 \%$ & $0,08 \%$ & $0,12 \%$ & $0,12 \%$ & $0,13 \%$ & $0,10 \%$ \\
\hline 12 SENI PERTUNJUKAN & $0,05 \%$ & $0,06 \%$ & $0,06 \%$ & $0,06 \%$ & $0,06 \%$ & $0,06 \%$ & $0,06 \%$ & $0,06 \%$ \\
\hline 13 RISET DAN PENGEMBANGAN & $0,02 \%$ & $0,03 \%$ & $0,03 \%$ & $0,04 \%$ & $0,04 \%$ & $0,04 \%$ & $0,04 \%$ & $0,03 \%$ \\
\hline 14 PERMAINAN INTERAKTIF & $0,00 \%$ & $0,01 \%$ & $0,01 \%$ & $0,01 \%$ & $0,01 \%$ & $0,02 \%$ & $0,03 \%$ & $0,01 \%$ \\
\hline Total & $100,00 \%$ & $100,00 \%$ & $100,00 \%$ & $100,00 \%$ & $100,00 \%$ & $100,00 \%$ & $100,00 \%$ & $100,00 \%$ \\
\hline
\end{tabular}

Kecenderungan lain yang dapat dijadikan indikator relevansi kurikulum dari industri kreatif bisang fesyen ini adalah jumlah usaha industri sebagaimana ditunjukkan pada tabel 4. Industri kreatif fesyen memiliki rata-rata kontribusi jumlah usaha dari tahun 2002 - 2008 sebesar 51,66\% atau sebanyak 1,47 juta usaha. Jumlah lapangan pekerjaan dalam bentuk perusahaan industri kreatif bidang fesyen ini menduduki peringkat teratas dibandingkan 13 sektor industri kreatif lainnya.

\section{Relevansi Kurikulum SMK Dimensi Lokasi}

Relevansi dimensi lokasi terkait dengan wilayah industri yang memerlukan pasokan tenaga kerja sesuai dengan kebutuhan. Salah satu indikator berkembang tidaknya industri kreatif di suatu wilayah dapat dilihat dari seberapa besar perhatian pemerintah maupun masyarakat luas terhadap industri kreatif.

Dunia maya pada saat ini menjadi salah satu media promosi yang sangat efektif bagi produsen maupun konsumen. Jumlah orang yang mengakses laman di dunia maya dapat menjadi salah satu indikator perhatian terhadap perkembangan 
industri kreatif. Jumlah laman yang mengulas industri kreatif di dunia maya baik skala lokal maupun nasional ditunjukkan pada gambar 5 .

Propinsi yang memiliki perhatian lebih pada industri kreatif, secara berturut-turut yaitu Yogyakarta, Balikpapan, dan Jawa Barat. Ketiga propinsi tersebut memiliki peluang yang lebih banyak untuk berkembangnya industri kreatif, sehingga dapat menjadi peluang pula bagi lulusan untuk bekerja di sektor industri kreatif tersebut. Jogyakarta dan Jawa Barat selama ini memang dikenal sebagai propinsi dengan kota tertentu yang memiliki ciri khas budaya, seni, dan industri kreatif yang berkembang dengan cukup baik yaitu Kota Bandung dan Jogyakarta. Balikpapan meskipun tidak sepopuler Daerah Istimesa Jogyakarta dan Jawa Barat, akan tetapi propinsi tersebut punya keinginan yang cukup besar untuk mengembangkan industri kreatif.

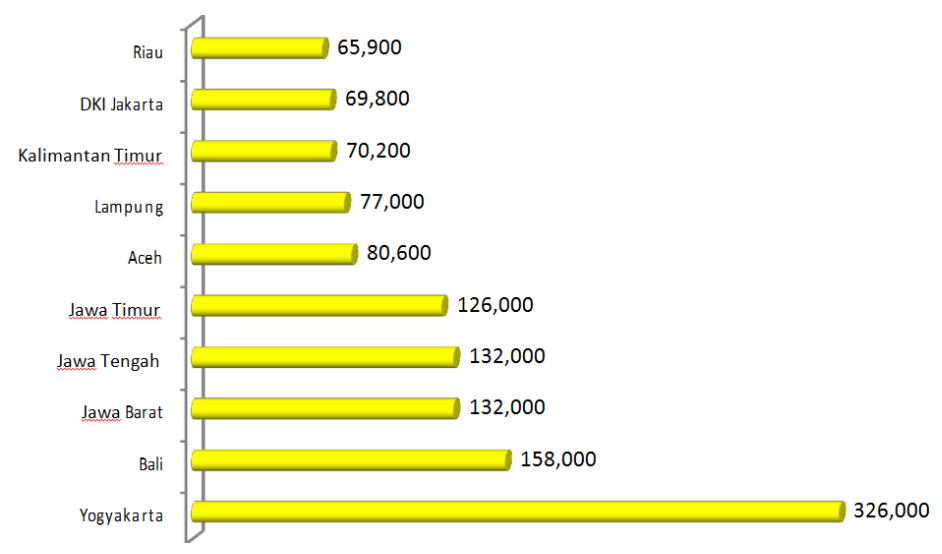

Sumber : Departemen Perdagangan RI (2009)

Gambar 5. Jumlah laman mengulas industri kreatif di tingkat propinsi

Apabila kajian dikerucutkan lagi kepada wilayah tingkat kota, maka gambar 6 menunjukkan bahwa peringkat industri kreatif teratas berturut-turut ditempati oleh Kota Bandung, Solo, Surabaya, dan Malang. Kota Bandung menempati kota dengan perkembangan industri kreatif tertinggi karena kota tersebut pada tahun 2007 ditetapkan sebagai pilot project kota industri kreatif seAsia Timur pada ajang pertemuan internasional yang dilaksanakan di Yokohama Jepang pada akhir Juli 2007 (Anggraeni,2008). Kota Bandung memang terkenal dengan keanekaragaman budaya dan seni serta didukung oleh relatif banyaknya lembaga pendidikan tinggi yang secara langsung dan tidak langsung menjadi dukungan tersendiri bagi perkembangan industri kreatif ini. Industri kreatif yang menjadi primadona di Bandung adalah industri kreatif bidang fesyen, yang 
dikenal sebagai "Paris Pan Java". Kondisi ini sebetulnya menjadi catatan tersendiri bagi para lulusan SMK Tata Busana. Kota Bandung dapat menjadi pilihan untuk berkarir dan mengembangkan diri dalam bidang industri kreatif bidang fesyen.

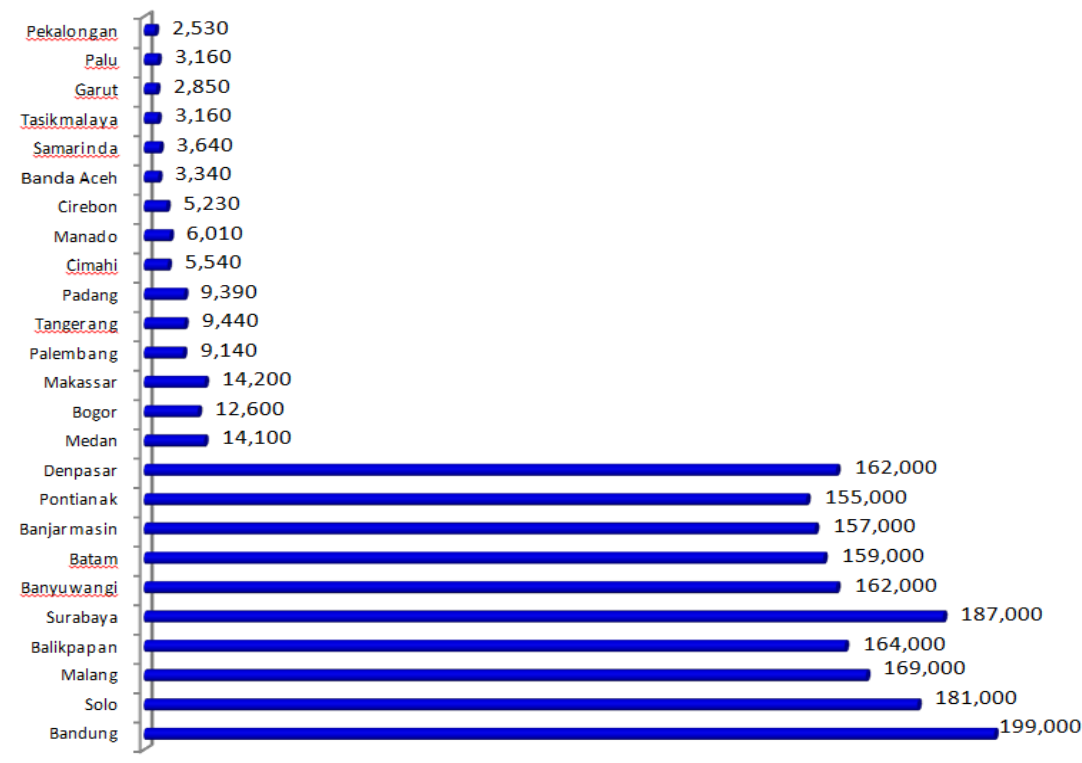

Sumber : Departemen Perdagangan RI (2009)

Gambar 6. Jumlah laman mengulas industri kreatif di tingkat kota

\section{Relevansi Kurikulum SMK Dimensi Waktu}

Relevansi kurikulum SMK dari dimensi waktu terkait dengan leadtime pendidikan atau perubahan kondisi ekonomi. Departemen Perdagangan RI $(2009 ; 2)$ menyatakan bahwa industri kreatif memiliki kecenderungan yang baik untuk pertumbuhan ekonomi lokal, nasional, dan global.

Kecenderungan industri kreatif masa kini dan masa depan perlu diakomodasi oleh dunia pendidikan dalam bentuk pengembangan dan pembenahan kurikulum, sebagaimana yang dikemukakan oleh Matthew (2010: 90 ) bahwa untuk menjaga relevansi antara program pendidikan kejuruan dengan dunia kerja maka: curriculum must be reviewed, enriched, and update regularly in line with changes that are taking place in the industries. Salah satu strategi yang dapat dilakukan adalah dengan terus mengkaji profil industri kreatif yang menjadi kecenderungan perkembangan ekonomi di suatu negara. Lebih tegas, Komla (2011:57) memberikan strategi bagaimana memastikan adanya relevansi pendidikan dengan kebutuhan dunia kerja. Komla memberikan tiga komponen 
yang perlu diperhatikan yaitu meeting the need individual, meeting the needs of the society, dan meeting the needs of the economy. DuPre (2011:8) bahkan menjamin apabila kurikulum yang dikembangkan telah relevan dengan kebutuhan dunia kerja, maka akan memberikan arah yang baik bagi pengembangan sistem ketenagakerjaan di masa depan this connection between education and employment is exemplified in today's depressed job market, whrere there are more applicants for fewer job.

\section{KESIMPULAN}

Kurikulum SMK Tata Busana yang relevan dengan kebutuhan industri kreatif fesyen dari dimensi kualitas terkait dengan pengembangan kompetensi hardskill dan softskill yang bertumpu pada nilai kreativitas. Kompetensi softskill yang relevan dengan kebutuhan industri tersebut adalah kreatifitas, keterbukaan, dan kemampuan memanfaatkan perkembangan teknologi terkini. Kompetensi hardskill yang relevan dengan kebutuhan industri kreatif fesyen adalah skill untuk memproduksi pakaian jadi.

Industri kreatif fesyen merupakan bidang yang paling tinggi memiliki daya serap, peluang pekerjaan, serta jumlah usaha yang tersedia. Kurikulum SMK Tata Busana akan menjadi relevan dalam konteks dimensi kuantitas apabila mengarahkan program keahlian untuk mampu mengisi peluang usaha tersebut.

Relevansi kurikulum SMK Tata Busana dari dimensi lokasi, memperlihatkan Kota Bandung menjadi kota pusat pengembangan industri kreatif bidang fesyen di Indonesia. SMK Program keahlian Tata Busana di Kota Bandung baik dari segi jumlah maupun kualitas menjadi sangat strategis untuk dikembangkan .

Relevansi kurikulum SMK Tata Busana yang dikembangkan mengacu pada industri kreatif fesyen dari dimensi waktu diyakini akan mampu meningkatkan perekonomian negara secara signifikan pada masa kini dan masa depan. 


\section{DAFTAR PUSTAKA}

Anggraini, N. 2008. “Industri Kreatif”. Jurnal Ekonomi, XIII(3),hlm.144-151.

Amankwah, E. and Swanzy, P. 2011. "The Role of Stakeholders in Building Adequate Competences in Students for the Job Market". International Journal of Vocational and Technical Education,Vol.3(8),pp.107-112.

Badan Penelitian dan Pengembangan Propinsi Jawa Tengah. 2008. Laporan Penelitian Tentang Keterkaitan Pendidikan dan Penyediaan Lapangan Kerja di Jawa Tengah.Semarang: BPPP Jawa Tengah

Canavan B \& Doherty R. 2005. Technical Curriculum in Scotland - Fit for Purpose? PATT-15 April 18-22, 2005 Technology Education and research: Twenty Years Retrospect.

Departemen Perdagangan RI. 2009. Studi Industri Kreatif Indonesia 2009. Hasil Konvensi Pengembangan Ekonomi Kreatif 2009-2015 Yang Diselenggarakan Pada Pekan Produk Budaya Indonesia 2009. JCC, 4 -8 Juni 2009

DuPre, C. and Williams, Kate. 2011. "Undergraduates' Perceptions of Employer Expectations", Journal of Career and Technical Education, Vol.26(1),pp.819.

Finch C.R and Cruncilton J.R .1992. Curriculum Development in vocational and Technical Education, Planning, Content, and Implementation . Fourth Edition . Allyn and Bacon.Boston London.

Hodge K.A. and Lear J.L. 2011. "Employment Skills for $21{ }^{\text {st }}$ Century Workplace: The Gap Between Faculty and Student Perceptions". Journal of Career and Technical Education, Vol.26,No.2,pp.28-41.

Keiser C, Jonathan, et.all . 2004. "Technical Education Curriculum Assessment" Journal of Vocational Education Research, Vol.29(3), pp.181-194.

Komla M.E and Ansah C.O.2011.'Linking Tertiary Institutions to industries: Evidence from the Vocational and Technical Education Departement of University of Cape Coast. International Journal of Vocational and Technical Education, Vol.2(5),pp.53-60.

Matthew O. A and Ede E.O. 2010. "Integration of New Technological Innovations in automobiles into the curriculum for Nigerian Technical College Programes". International Journal of Vocational and Technical Education, Vol.2(5),pp.89-94.

Miller D. M. 1985. Principles and A Philosophy for Vocational Education. The National Center for Research in Vocational Education The Ohio State University. Columbus, Ohio 43210. 
Munandar, U. 1999. Pengembangan Kreativitas Anak Berbakat. Jakarta.Rineka Cipta.

GTZ. 2009. Sustainable Economic Development Supported by Improving Technical and Vocational Education : Minutes of Meeting on the Mission's Outcome. GTZ Annual Report 2009.

Oloruntegbe, K.,O.; et.al. 2010. "Reconceptualization of African Vocational and Technological Education for Emergent Globalization, Relevance and Suistainable Economic Developtment “.International Journal of Vocational and Technical Education, Vol.2(4),pp.55-61.

Pangestu, M.,E. 2008. Pengembangan Ekonomi Kreatif Indonesia 2025. Departemen Perdagangan RI.

Sanjaya,W. 2008. Kurikulum dan Pembelajaran .Teori dan Praktik Pengembangan Kurikulum Tingkat Satuan Pendidikan (KTSP). Jakarta: Kencana Predana Media Group.

Renstra Kemendiknas 2010-2014. Kementerian Pendidikan Nasional

Tim Ahli Penyelarasan Pendidikan dan Dunia Kerja. 2011. Kerangka Kerja Penyelarasan Pendidikan dengan Dunia kerja. Sosialisasi Program Penyelarasan Pendidikan dengan Dunia Kerja Kopertis Wilayah VII.Surabaya, 23 Desember 2011.

Undang-Undang Sistem Pendidikan Nasional No.20 Tahun 2003. 